УДК 347

DOI https://doi.org/10.32837/pyuv.v0i5(34).647

\author{
С.В. Дяченко
}

orcid.org/0000-0002-0104-2769

кандидат юридичних наук, доиент,

доиент кафедри иивільного права та проиесу

Університету державної фіскальної служби України

\author{
В. В. Красько \\ orcid.org/0000-0002-2348-9908 \\ студентка магістратури \\ Навчально-наукового інституту права \\ Університету державної фіскальної служби України
}

\title{
ДОМОВИТИСЬ НЕ МОЖНА СУДИТИСЬ
}

Право на судовий захист є одним із найважливіших гарантій забезпечення та відновлення порушених прав і свобод людини. Воно забезпечується Конституцією України - основним законом нашої держави, норми якого володіють прямою дією та найвищою силою, що надає змогу громадянам звертатись до суду на підставі її положень.

Із набуттям чинності змін, внесених до Цивільного процесуального кодексу - 15.12.2017 року, законодавець інтегрував в судовий процес нову процедуру захисту - врегулювання спору за участю судді, та розширив можливість застосування альтернативних способів вирішення цивільно-правових спорів. Однак сьогодні не існує однозначного розуміння змісту введеної новели, особливостей її застосування, а також значення та правових наслідків для сторін, які беруть у ній участь.

Метою статті є дослідження специфіки досудового врегулювання спорів, особливостей нового цивільно-процесуального інституту - врегулювання спору за участю судді як альтернативного способу вирішення спорів, його процесуальних наслідків та висвітлення проблематики застосування із використанням практичних кейсів судової практики.

Окремими питаннями альтернативних способів врегулювання цивільно-правових спорів займались такі теоретики та практики, як Н. Бондаренко-Зелінська, Н. Грень, С. Дяченко, Г. Єременко, Н. Килинник, Н. Кіреєва, В. Кудрявцева, О. Можайкіна, Є. Приймак, Л. Романадзе, О. Тиханський, М. Поліщук, Т. Цувіна.

Безпосередньо врегулюванню спору за участю судді присвячували свої праці Г. Гончарова, С. Запара, О. Кармаза, В. Комаров, С. Кузьменко, Д. Кушерець, Н. Мазаракі, Ю. Притика, В. Рєзнікова, Н. Турман, С. Фурса.

Вагомий внесок у дослідження цього питання здійснили зарубіжні науковці, як-от: Н. Александер, Л. Боулл, Х. Бесмер, Е. Ватцке, М. Герзон, Л. Герін, Г. Девіс, Р. Керролл, П. Ловенхайм, М. Манн, М. Робертс, Дж. Уінслейд.
Курс України до зайняття місця в Свропейському Співтоваристві та утвердження європейських стандартів вимагає реагування на сучасні правові тенденції щодо надання вибору сторонам цивільно-правового спору форми захисту на засадах альтернативності. Підтримання нашою країною цієї позиції знайшло своє відображення в Указі Президента України «Про концепцію вдосконалення судівництва для утвердження справедливого суду в Україні відповідно до європейських стандартів» .

Тому науці цивільного процесуального права, окрім загальноприйнятого судового способу захисту прав та інтересів осіб, стали відомі також альтернативні методи досудового врегулювання спорів.

Такі альтернативні механізми являють собою систему взаємопов'язаних дій сторін та інших осіб із розгляду наявного спору, спрямованих на його позасудове врегулювання або вирішення із застосуванням примирних чи інших не заборонених законом процедур, що здійснюються зазвичай на підставі сумлінного волевиявлення сторін [2, с. 180-223].

Основними перевагами альтернативних способів захисту є: спрощена процедура та відсутність елемента доказування; відсутність формальних правил поведінки; вільний вибір посередника (арбітра, медіатора тощо); конфіденційність та негласність вирішення спору; можливість особистого контролю ходу процедури; необмеженість у часі; приватний характер [3, с. 12].

Важливою ознакою нетрадиційних способів захисту є добровільне волевиявлення сторін на їх застосування. Серед них можна виокремити переговори, посередництво (медіацію), примирення, арбітраж тощо.

Необхідно відрізняти судову медіацію від класичної. Поняття «медіація» походить від лат. "mediare", що означає «бути посередником". У перекладі з англійської мови термін «медіація» (mediation) означає посередництво, клопотання, заступництво [4, с. 119]. 
Під загальноприйнятим терміном «медіація» розуміють вирішення цивільно-правового спору сторонами за сприяння неупередженого, незацікавленого посередника (медіатора), роль якого полягає у досягненні примирення сторін та відповідної угоди. Однак сьогодні це питання не регламентовано на національному рівні та не існуе спеціального закону, який регулює здійснення процедури «медіації» в Україні.

Своєю чергою врегулювання спору за участю судді регламентується главою 4 Розділу III ЦПК України [5]. Крім того, їх не варто ототожнювати за порядком реалізації, адже вирішення спору за участю судді можливе до початку розгляду справи по суті, а медіація - на будь-якому етапі. Тривалість медіації визначається за згодою сторін, а врегулювання спору за участю судді відбувається протягом розумного строку, але не більше тридцяти днів із дати прийняття рішення про врегулювання.

Також процедура медіації та особа медіатора визначається лише сторонами, своєю чергою досудове врегулювання спору за участю судді відбувається відповідно до положень ЦПК України та реалізується особою, яка здійснює правосуддя на професійній основі - суддею. Варто звернути увагу, що медіатор налагоджує комунікацію між сторонами, які самостійно обирають оптимальне рішення для них, суддя ж наділяється правом надати власні пропозиції щодо мирного вирішення спору.

Однак необхідно виокремити і деякі спільні риси таких альтернативних способів вирішення справи, зокрема, оперативність розгляду, вибір прийнятного рішення для обох сторін, конфіденційний характер, гнучкість вирішення спору та реалізація засад добровільності.

Тому можна вважати, що введення такого цивільно-процесуального інституту, як судова медіація, може бути ефективним інструментом для вирішення справ, прогресивним кроком до удосконалення процесуального законодавства та приведення його у відповідність до міжнародних стандартів.

Врегулювання спору за участю судді в Україні на даному етапі займає провідну позицію щодо забезпечення прав людини на справедливий судовий захист із використанням мінімальних матеріальних та часових ресурсів. Однак необхідно розуміти деякі особливості його застосування та правові наслідки, які виникають в результаті проведення такої процедури.

Порядок врегулювання спору за участю судді регламентується главою 4 Цивільного процесуального кодексу України [5]. Статтею 201 передбачено, що така процедура може здійснюватися лише за згодою обох сторін до початку розгляду справи по суті. Важливо відмітити, що у разі вступу у процес третьої сторони, яка заявляє самостійні вимоги щодо предмету спору, врегулювання за участю судді неможливе.

Суд розпочинає проведення такої процедури постановленням ухвали, якою автоматично зупиняє провадження у справі. Якщо протягом строку врегулювання сторони не досягнуть консенсусу, передбачена заборона на його повторне проведення.

Процедура врегулювання проходить у формі спільних та закритих нарад, в яких сторони можуть брати участь також у режимі відеоконференції. На спільних нарадах присутні сторони, ï представники та суддя, а на закритих суддя за власною ініціативою спілкується 3 кожною стороною окремо.

Початковий етап першої спільної наради супроводжується роз'ясненням суддею сторонам мети, порядку врегулювання спору та їх прав і обов'язків.

На наступних спільних нарадах суддя роз'яснює підстави та предмет позову, підстави заперечень, предмет доказування за категорією такого спору, запитує сторони про їх пропозиції щодо шляхів вирішення спору та здійснює інші дії з метою спрямування на мирне врегулювання конфлікту. Суддя також може запропонувати власний варіант мирного врегулювання. Однак забороняється надавати сторонам юридичні поради чи оцінку доказів у справі.

У процесі проведення закритих нарад суддя може звертати увагу кожної із сторін на судову практику, яка стосується їх питання, та пропонувати можливі шляхи врегулювання спору стороні та її представнику. Інформація, яка обговорюється на закритих нарадах та в межах врегулювання спору за участю судді, є конфіденційною і не фіксується будь-якими технічними засобами чи протоколом. Перекладач, якого можуть залучати до участі, також попереджається про конфіденційність інформації. Передбачено окрему заборону щодо використання під час врегулювання спору портативних аудіотехнічних пристроїв, а також здійснення фото- і кінозйомки, відео-, звукозапису.

Своєю чергою статтею 204 ЦПК України закріплено підстави припинення врегулювання спору за участю судді, серед них: подання однією із сторін заяви про припинення такої процедури, закінчення строку врегулювання, затягування процесу сторонами, а також укладення мирової угоди між сторонами та звернення до суду із заявою про іï затвердження або звернення позивача до суду із заявою про залишення позовної заяви без розгляду, або в разі відмови позивача від позову чи визнання позову відповідачем [5].

За результатами припинення процедури врегулювання суддя постановляє ухвалу, яка не може бути оскаржена, та вирішує питання щодо поновлення провадження у справі. 
Важливо нагадати, що врегулювання спору за участю судді здійснюється протягом розумного строку, але не більше тридцяти днів з дня постановлення ухвали про його проведення, такий строк не може бути продовжений.

Враховуючи вищезазначені положення, головною метою врегулювання спору за участю судді $\epsilon$ прагнення вирішення спору між сторонами до початку судового розгляду задля заощадження часу та додаткових судових витрат.

Узагальнена судова практика 2018-2019 років свідчить про те, що врегулювання спору за участю судді застосовується щодо таких категорій справ, як розірвання шлюбу, стягнення аліментів, поділ майна, договірні спори, трудові спори щодо захисту права власності, житлові спори.

Однак судові рішення також демонструють проблеми, які можуть виникати під час застосування процедури врегулювання спору за участю судді. Наприклад, під час підготовчого провадження заяву про врегулювання спору за участі судді подає лише одна із сторін. В такому разі суд відмовляє у проведенні даної процедури на підставі ч. 1 ст. 201 ЦПК України (Ухвала Заводського районного суду м. Миколаєва від 28.09.2018 у справі № 487/2389/17). Також врегулювання спору за участі судді припиняється у зв'язку із закінченням строків такого врегулювання (Ухвала Комсомольського міського суду Полтавської області від 04.10.2018 у справі № 534/442/18). 3 позитивних результатів, це укладення мирової угоди (Ухвала Болградського районного суду Одеської області про затвердження мирової угоди від 06.04.2018 у справі № 497/935/17) [6].

Також необхідно зауважити, що застосування досудового врегулювання спору не повинно вважатись обов'язковою умовою звернення до суду. На цьому наголошує і Європейський суд з прав людини, який підтримує позицію, що право на доступ до правосуддя може бути обмеженим у визначених випадках, однак такі обмеження в жодному разі не повинні зменшувати рівень такого доступу, адже знецінюється сутність цього права. Обмеження не будуть сумісними 3 п. 1 ст. 6 Конвенції про захист прав людини і основоположних свобод, якщо вони не переслідують «законної мети» та якщо відсутня «розумна співрозмірність між засобами, що використовуються, та метою, яка переслідується» [7].

Тому застосування процедури досудового врегулювання спору за участю судді не залежить від обов'язковості їі застосування, наслідків виконання чи невиконання та не впливає на право ініціювання звернення за судовим захистом. В такому разі право на судовий захист в жодному разі не $є$ втраченим, а повинно оптимізуватись шляхом запровадження альтернативних способів врегулювання спорів.
Крім практики ЄСПЛ, це правило випливає із частини 5 статті 55 Конституції України, яка гарантує кожному право будь-якими не забороненими законом засобами захищати свої права і свободи від порушень та протиправних посягань [8].

Враховуючи положення Основного закону, Конституційний Суд України у справі про досудове регулювання (Рішення від 9 липня 2002 року №15-рп/2002) зазначив, що право на судовий захист не позбавляє суб'єктів правовідносин можливості досудового врегулювання спорів [9].

Це може бути передбачено цивільно-правовим договором, коли суб'єкти правовідносин добровільно обирають засіб захисту їх прав. Досудове врегулювання також може мати місце за волевиявленням кожного з учасників правовідносин, за відсутності у договорі застереження щодо врегулювання такого спору [9].

Відтак обрання певного засобу правового захисту, враховуючи досудове врегулювання спору, є правом, а не обов'язком особи, яка на добровільних засадах, виходячи з власних інтересів, його використовує. Встановлення законом обов'язкового досудового врегулювання спору $є$ недопустимим, адже обмежується можливість права на судовий захист.

Таку ж позицію продемонстрував Верховний Суд України у своїй Постанові від 27 травня 2020 року у справі № 2-2134/2010) [10].

Зразковим є рішення Конституційного Суду України від 9 липня 2002 року по справі №1-2/2002. У ньому передбачено, що обов’язкове досудове врегулювання спорів, яке виключає можливість прийняття позовної заяви до розгляду і здійснення за нею правосуддя, порушує право особи на судовий захист. Можливість використання суб'єктами правовідносин досудового врегулювання спорів може бути додатковим засобом правового захисту, який держава надає учасникам певних правовідносин, що не суперечить принципу здійснення правосуддя виключно судом. 3 огляду на необхідність підвищення рівня правового захисту держава може стимулювати вирішення правових спорів у межах досудових процедур, однак їх використання є правом, а не обов'язком особи, яка потребує такого захисту [11].

У Постанові Верховного Суду України від 19 вересня 2018 року по справі № 719/240/16-ц суди дійшли обгрунтованого висновку про те, що оприлюднення списків боржників не свідчить про протиправну поведінку відповідача, оскільки чинним законодавством не встановлено прямої заборони підприємству в такий спосіб захищати свої права, а направлення ДКПУ «Тепловодоканал» позивачу письмових претензій щодо погашення заборгованості є одним із способів досудового врегулювання спорів [12]. 
Постановою від 14 лютого 2018 року у справі № 464/7725/15 вказано, що згідно зі статтею 16 ЦК України кожна особа має право звернутися до суду за захистом свого особистого немайнового або майнового права та інтересу. Кожен має право на розгляд його справи судом, що відповідає вимогам статті 6 Конвенції про захист прав людини і основоположних свобод [13].

Судами визначено, що особа лише з власних переконань обирає засіб судового захисту, ніхто не може її примусити до досудового врегулювання спору, а також позбавити звернення до суду для захисту своїх прав.

Тому суди попередніх інстанцій правильно вважали, що право особи звернутися до суду за захистом свого права реалізується незалежно від можливості здійснити врегулювання спору в позасудовому порядку.

Висновки. Досудове врегулювання є новелою цивільного судочинства, перевагами якого є гнучкість, швидкість, економність та конфіденційність. Серед альтернативних способів захисту в Цивільному процесуальному кодексі України регламентовано порядок здійснення досудового врегулювання спору за участю судді. Його також називають судовою медіацією, яка відрізняється від звичайної за нормативним закріпленням, тривалістю процедури, механізмом реалізації, суб'єктами.

Тому пропонуємо ввести визначення поняття «судової медіації» як додаткового засобу правового захисту, що передбачає вирішення спору на добровільних засадах та спрямований на підвищення рівня судового захисту прав та свобод особи, а не його обмеження.

Проаналізувавши судову практику національних судів та Європейського суду з прав людини щодо правових наслідків застосування чи незастосування досудового врегулювання, необхідно підсумувати, що відповідно до права, а не обов'язку особи на досудове врегулювання вона самостійно вирішує чи застосовувати його. Ніхто не може бути примушений до досудового врегулювання. Про це свідчить і назва нашої статті - «Домовитись не можна судитись», яка надає можливість кожному вирішити для себе, де саме потрібно поставити розділовий знак. Своєю чергою держава повинна забезпечити належну реалізацію будьякого вибору особи відповідними нормативноправовими актами.

Тому право кожної особи на правосуддя має бути забезпечене створенням ефективної системи захисту порушених, невизнаних чи оспорюваних прав, свобод та інтересів громадян і прогресивним розвитком правових механізмів альтернативного вирішення приватноправових спорів, які будуть інтегруватись із правом на безпосереднє звернення до суду, а не обмежувати його.

\section{Jimepamypa}

1. Про концепцію вдосконалення судівництва для утвердження справедливого суду в Україні відповідно до європейських стандартів: Указ Президента Україні від 10 травня 2006 р. № 361/2006 // БД «Законодавство України»/ ВР України. URL: https://zakon.rada.gov.ua/laws/show/361/2006 (дата звернення: 01.12.2020).

2. Здрок О.Н. Примирительные процедуры в гражданском судопроизводстве: понятие, классификация, тенденции развития (на примере Республики Беларусь). Вестник гражданского процесса. 2012. № 1. C. $180-223$.

3. Божук I., Дяченко С. Судова практика застосування альтернативних способів врегулювання спорів. Підприємництво, господарство і право. 2019. № 12. С. $11-15$.

4. Дяченко С.В., Колокольна Н.С. Запровадження медіації для вирішення сімейних спорів у цивільному судочинстві України: судова практика. Юридичний науковий електронний журнал. 2020. № 2. С. 118-122.

5. Цивільний процесуальний кодекс України: Закон України від 18 квітня 2004 р. № 1618-I // БД «Законодавство України» / ВР України. URL: https://zakon.rada.gov.ua/laws/ show/1618-15 (дата звернення: 01.12.2020).

6. Дяченко С.В., Бичок Т.П. Актуальні питання врегулювання спору за участю судді. Юридичний науковий електронний журнал. 2018. № 6. С. 86-89.

7. Ashingdane v. United Kingdom, no. 8275/78, $\S 57$, Series A no. 93 URL: http://hudoc.echr.coe.int/ eng? $\mathrm{i}=001-57425$ (дата звернення: 01.12.2020).

8. Конституція України: Закон від 28 червня 1996 року. № 254к/96-ВР. Відомості Верховної Ради України. 1996. № 30 .

9. Рішення Конституційного Суду України від 9 липня 2002 року у справі № 15-рп/2002. URL: https://zakon.rada.gov.ua/laws/show/v015p71002\#Text (дата звернення: 01.12.2020).

10. Постанова Верховного Суду України від 27 травня 2020 року у справі № $2-2134 / 2010$. URL: https://reyestr.court.gov.ua/Review/89518632 (дата звернення: 01.12.2020).

11. Рішення Конституційного Суду України від 9 липня 2002 року у справі № 1-2/2002. URL: https://zakon.rada.gov.ua/laws/show/v015p71002\#Text (дата звернення: 01.12.2020).

12. Постанова Верховного Суду України від 19 вересня 2018 року у справі № $719 / 240 / 16$-ц. URL: https://reyestr.court.gov.ua/Review/76673100 (дата звернення: 01.12.2020).

13. Постанова Верховного Суду України від 14 лютого 2018 року у справі № 464/7725/15. URL: https://reyestr.court.gov.ua/Review/72459931 (дата звернення: 01.12.2020).

\section{Анотація}

Дяченко С. В., Красько В. В. Домовитись не можна судитись. - Стаття.

У статті досліджено специфіку досудового врегулювання цивільних спорів та визначено, що це сукупність дій учасників спору, які спрямовані на вирішення конфлікту із використанням позасудових процедур, що не заборонені цивільним процесуальним законодавством та базуються на вільному волевиявленні сторін.

Висвітлено основні переваги альтернативних способів вирішення цивільних спорів. Серед них спрощена процедура, вільний вибір посередника, відсутність еле- 
мента доказування, конфіденційність, необмеженість в часі, відсутність надмірного формалізму, добровільне волевиявлення.

Встановлено, що «судова медіація» та «медіація» не $є$ тотожними поняттями. Критеріями розмежування є порядок реалізації, тривалість процедури, суб'єктивний склад, функціональні повноваження посередників.

Визначено особливості новели цивільного процесуального законодавства - врегулювання спору за участю судді, та запропоновано визначати судову медіацію як додатковий засіб правового захисту, що передбачає вирішення спору на добровільних засадах та спрямований на підвищення рівня судового захисту прав та свобод особи, а не його обмеження.

3'ясовано, що така альтернативна процедура $\epsilon$ одним із ефективних способів вирішення спорів, яка забезпечує вирішення справи за допомогою мінімальних матеріальних та часових ресурсів. Головною метою досудового врегулювання спору за участю судді $\epsilon$ прагнення вирішення спору між сторонами до початку судового розгляду задля заощадження часу та додаткових судових витрат.

Досліджено проблемні аспекти, які можуть виникати під час застосування судової медіації, а також її позитивні результати, що обгрунтовано судовою практикою.

В результаті дослідження встановлено, що вибір досудового врегулювання спору за участю судді є правом, а не обов'язком особи, яке не обмежує можливості реалізації права на судовий захист. Альтернативний спосіб захисту обирається особою з власних переконань та не позбавляє звернення безпосередньо до суду за захистом своїх прав, а держава повинна створити необхідні умови для підтримання ії вибору та оптимізації ефективного функціонування досудового та судового врегулювання цивільних спорів.

Ключові слова: альтернативні способи захисту, досудове врегулювання за участю судді, обов'язкова умова, право на судовий захист, судова практика.

\section{Summary}

Dyachenko $S . V$., Krasko $V$. V. It is impossible to agree to sue. - Article.

The article examines the specifics of pre-trial settlement of civil disputes and determines that it is a set of actions of civil litigants, which are aimed at resolving the conflict using out-of-court procedures, which are not prohibited by civil procedural law and based on free will.

The main advantages of alternative ways of resolving civil disputes are highlighted. Among them are a simplified procedure, free choice of mediator, lack of evidence, confidentiality, unlimited time, lack of excessive formalism, voluntary expression of will.

It has been established that «judicial mediation» and «mediation» are not identical concepts. The criteria for differentiation are the order of implementation, the duration of the procedure, the subjective composition, the functional powers of the mediator and the judge.

The peculiarities of the novelty of civil procedural legislation - dispute resolution with the participation of a judge are determined and it is proposed to define judicial mediation as an additional remedy, which provides for resolving the dispute on a voluntary basis and aims to increase judicial protection of individual rights and freedoms.

It has been found that such an alternative procedure is one of the effective ways of resolving disputes, which ensures the resolution of the case with minimal material and time resources. The main purpose of pre-trial dispute resolution with the participation of a judge is the desire to resolve the dispute between the parties before the trial in order to save time and additional court costs.

The problematic aspects that arise in the application of judicial mediation, as well as its positive results are studied, which is substantiated by judicial practice.

The study found that the choice of pre-trial dispute resolution with the participation of a judge is a right, not a duty of a person, which does not limit the possibility of exercising the right to judicial protection. The alternative method of protection is chosen by the person from his own convictions and does not deprive him of going directly to court to protect his rights. The state does not deprive the right to judicial protection, but creates the necessary conditions to maintain its choice and optimize the effective functioning of pre-trial and judicial settlement of civil disputes.

Key words: alternative methods of protection, pre-trial settlement with the participation of a judge, mandatory condition, the right to judicial protection, judicial practice. 